\title{
PENINGKATAN HASIL BELAJAR SERVIS BAWAH BOLAVOLI DENGAN MENGGUNAKAN METODE PROBLEM SOLVING PADA PESERTA DIDIK KELAS X SMKN 1 JATIREJO KABUPATEN MOJOKERTO TAHUN PELAJARAN 2017/2018
}

\author{
Mukhamad Ilkamto', Yudi Dwi Saputra²
}

Program Studi Pendidikan Jasmani dan Kesehatan STKIP PGRI Jombang

\begin{abstract}
Abstrak
Penelitian ini bertujuan untuk mengetahui peningkatan hasil belajar peserta didik pada mata pelajaran pendidikan jasmani dan kesehatan melalui metode problem solving. Dalam hal ini peneliti berpandangan bahwa aspek tersebut dapat meningkatkan hasil belajar peserta didik. Berdasarkan fakta yang terjadi di lapangan saat ini siswa kurang aktif dalam proses pembelajaran, sehingga ketuntasan hasil belajar siswa pra siklus sebesar $56 \%$ dari 30 jumlah seluruh siswa kelas $\mathrm{X}$. Penggunaan metode problem solving yang diharapkan mampu meningkatkan hasil belajar siswa.Dalam penelitian ini peserta didik Kelas $X$ yang berjumlah 30 siswa adalah sebagai obyek penelitian, sedangkan teknik analisis datanya menggunakan statistik sederhana yaitu menghitung ketuntasan secara perorangan serta ketuntasan secara klasikal. Penelitian ini merupakan penelitian tidakan kelas yang terdiri dari dua siklus dimana setiap siklus terdiri 4 tahap yaitu perencanaan, pelaksanaan, pengamatan, dan refleksi. Berdasarkan dari data hasil belajar peserta didik pada siklus I dengan nilai rata-rata 64.41 dan persentase ketuntasan secara keseluruhannya sebesar $60 \%$. $80 \%$ mencapai ketuntasan secara klasikal dengan nilai rata-rata 75.74 pada siklus II, Hasil Penelitian tersebut menunjukkan bahwa metode problem solving dapat meningkatkan hasil belajar peserta didik pada mata pelajaran pendidikan jasmani dan kesehatan.
\end{abstract}

Kata Kunci : Hasil Belajar, Metode pembelajaran Problem Solving

\section{Abstract}

This study aims to determine the improvement of learning outcomes of learners on subjects of physical education and health through problem solving methods. In this case the researcher believes that these aspects can improve student learning outcomes. Based on the facts that occur in the field is currently less active students in the learning process, so that the completeness of pre-cycle student learning results of $56 \%$ of 30 the total number of students of class X. Use of problem solving method is expected to improve student learning outcomes. In this study students Class $X$ numbered 30 students are as research objects, while the technique of data analysis using simple statistics that calculate the mastery individually as well as mastery in a classical. This study is a class action research consisting of two cycles where each 
cycle consists of 4 stages of planning, implementation, observation, and reflection. Based on the data of learning outcomes of learners in the first cycle with an average score of 64.41 and the percentage of overall mastery by $60 \% .80 \%$ reached the completeness in classical with the average value of 75.74 in cycle II, The result of this research show that problem solving method can improve learners' learning outcomes in physical education and health subject.

Keywords: Learning Outcomes, Problem Solving Learning Method

\section{PENDAHULUAN}

Pendidikan jasmani dan kesehatan itu pendidikan melalui gerak manusia. Akibat dari hal tersebut, maka pembelajaran pendidikan jasmani dan kesehatan harus mampu mengembangkan seluruh aspek pribadi manusia, dan harus berpegang teguh kepada norma-norma pendidikan. Dasar dasar pendidikan jasmani dan kesehatan merupakan peganggan pelaksanaan tugas. (Sukintaka, 2008:36).

Guru merupakan personal sekolah yang memiliki kesempatan untuk bertatap muka lebih banyak dengan siswa dibandingkan dengan personal sekolah lainnya. Oleh sebab itu, guru mempunyai peran dan tanggung jawab yang besar dalam pelaksanaan bimbingan dan konseling di sekolah.

Pembelajaran pendidikan jasmani dan kesehatan pada siswa kelas $X$ multimedia mencakup materi permainan bola besar, permainan bola kecil, senam ketangkasan, aktifitas ritmik, dan atletik. Materi permainan bola besar meliputi sepak bola, bola basket, dan bolavoli.

Penguasaan terhadap teknik dasar bermain bolavoli merupakan unsur pokok dalam pembelajaran bolavoli. Tolak ukur keberhasilan dalam pengajaran bolavoli adalah penguasaan keterampilan teknik dasar meliputi servis, passing, smash (spike), bendungan (block). Peneliti mencoba melakukan penelitian di SMKN 1 Jatirejo di karenakan sekolah tersebut terletak jauh dari perkotaan, letak sekolah 
tersebut yaitu di kec Jatirejo Kab Mojokerto. Peneliti mencoba melakukan penelitian dengan harapan ingin melihat ada atau tidaknya masalah dalam proses

pembelajaran bolavoli. Dikarnakan sekolah tersebut hanya memiliki 1 lapangan bola voli sedangkan dari jumlah siswa sendiri terdiri dari berbagai kelas. Mulai dari tiap jurusan terdiri dari 2 kelas, sedangkan di SMKN 1 Jatirejo memiliki 7 jurusan yaitu Teknik kendaraan ringan, Busana Butik, Multimedia, Teknik Otomotif Sepeda Motor, Teknik Instalasi Tenaga Listrik, Teknik Mekanik Industri, Akuntansi. Berdasarkan hasil observasi pada tanggal 07 Maret 2017, sebelumnya siswa dari kelas $\mathrm{X}$ multimedia $\mathrm{X} 1$ Multimedia,dan $\mathrm{X} 11$ Multimedia SMKN 1 Jatirejo masih banyak siswa yang sering melakukan kesalahan dalam melakukan Servis bawah bolavoli yaitu siswa kelas $X$ Multimedia yang memperoleh nilai teknik dasar Servis bawah dibawah kriteria ketuntasan minimal (KKM). Hal tersebut di karnakan sikap awal pada saat melakukan servis bawah sudah tidak benar, yang seharusnya lutut agak di tekuk sedikit dan berat badan berada di tengah. Akan tetapi siswa hanyalah berdiri tegak tanpa adanya lutut yang agak di tekuk, hal ini dapat mempengaruhi laju arah bola dan juga ketepatan bola yang akan di tuju. Kemudian juga dengan ayunan masih banyak siswa yang asal-asalan dalam proses mengayunkan ke'arah depan atas mengenai bagian belakang bawah bola, padahal ayunan sangat mempengaruhi ketepatan bola. Berdasarkan hasil belajar Servis bawah bolavoli yang diperoleh siswa sebelumnya yaitu $56 \%$ dari 30 siswa yang dihitung dengan menggunakan rumus

ketuntasan klasikal. Berdasarkan Kurikulum Tingkat Satuan Pendidikan (KTSP) nilai KKM yang harus ditempuh oleh siswa adalah 75. Hal ini di sebabkan karna kurang antusiasnya peserta didik dalam pembelajaran bolavoli. Oleh karena 
itu, perlu adanya upaya untuk meningkatkan hasil belajar teknik dasar Servis bawah bolavoli.

Berdasarkan permasalahan di atas, maka diperlukan metode pembelajaran yang tepat salah satunya dengan cara menerapkan metode pembelajaran yang sesuai dengan pendidikan jasmani dan kesehatan di sekolah. Sebelumnya guru SMKN 1 Jatirejo menerapkan metode mengajar dengan menggunakan metode Ceramah dan Demonstrasi. Diharapkan metode pembelajaran yang tepat dan sesuai dengan materi pelajaran dapat membantu tercapainya tujuan pendidikan. Menurut Huda (2013:273) menjelaskan bahwa metode pembelajaran pendekatan berpikir dan berbasis masalah meliputi problem based learning, problem solving learning, problem posing learning, open ended learning probing prompting learning, dan masih banyak yang lain. Salah satu metode pembelajaran yang dapat diterapkan pada sekolah ini adalah metode pemecahan masalah, peneliti mencoba menggunakan problem solving dengan harapan para siswa SMKN 1 JATIREJO dapat meningkatkan hasil belajar servis bawah dalam pembelajaran pendidikan jasmani dan kesehatan.

Untuk mengetahui secara pasti apakah penerapan metode belajar sesuai dan efektif guna meningkatkan hasil belajar Servis bawah bolavoli pada siswa kelas X SMKN 1 Jatirejo Kabupaten Mojokerto, perlu dikaji lebih mendalam dengan penelitian yang berjudul peningkatkan hasil belajar Servis bawah bolavoli dengan menggunakan metode problem solving pada peserta didik kelas X SMKN 1 Jatirejo kabupaten Mojokerto Tahun pelajaran 2017/2018

\section{METODE}

Penelitian ini merupakan penelitian tindakan kelas (classroom action research). Dari namanya sudah menunjukkan isi yang terkandung di dalamnya, 
yaitu kegiatan penelitian yang dilakukan di kelas. Menurut Arikunto, dkk (2010:2-3) ada tiga kata yang membentuk pengertian tersebut, maka ada tiga pengertian yang dapat diterangkan.Penelitian yaitu menunjuk pada suatu kegiatan mencermati suatu obyek dengan menggunakan cara dan aturan metodologi tertentu untuk memperoleh data atau informasi yang bermanfaat dalam meningkatkan mutu suatu hal yang menarik minat dan penting bagi peneliti.

Tindakan yaitu menunjuk pada sesuatu gerak kegiatan yang sengaja dilakukan dengan tujuan tertentu. Dalam penelitian berbentuk rangkaian siklus kegiatan untuk siswa.

Kelas yaitu dalam hal ini tidak terikat pada pengertian ruang kelas, tetapi dalam pengertian yang lebih spesifik. Seperti yang sudah lama dikenal dalam bidang pendidikan dan pengajaran, yang dimaksud dengan istilah kelas adalah sekelompok siswa yang dalam waktu yang sama, menerima pelajaran yang sama dari guru yang sama pula.

\section{HASIL DAN PEMBAHASAN}

Adapun hasil siklus pertama sebagai berikut:

1) Proses Pembelajaran Kelas

Tabel 4.1 Pengamatan Proses Pembelajaran Siklus Pertama

\begin{tabular}{|c|l|c|c|c|c|}
\hline No & \multicolumn{1}{|c|}{ Obyek yang diamati } & $\mathbf{4}$ & $\mathbf{3}$ & $\mathbf{2}$ & $\mathbf{1}$ \\
\hline 1 & Minat belajar siswa dalam pembelajaran & & & $\sqrt{ }$ & \\
\hline 2 & Kesungguh-sungguhan siswa & & $\sqrt{ }$ & & \\
\hline 3 & Keseriusan siswa & & & $\sqrt{ }$ & \\
\hline 4 & Keaktifan siswa selama pembelajaran & & & $\sqrt{ }$ & \\
\hline 5 & Kerjasama antar siswa dalam kelompok & & & $\sqrt{ }$ & \\
\hline 6 & Kehangatan suasana pembelajaran & & $\sqrt{ }$ & & \\
\hline 7 & Ketertiban siswa & & & $\sqrt{ }$ & \\
\hline 8 & Keriuhan dan gerak-gerik siswa & & & $\sqrt{ }$ & \\
\hline 9 & Kelancaran langkah-langkah pembelajaran & & $\sqrt{ }$ & & \\
\hline 10 & Ketepatan selesainya proses pembelajaran & & $\sqrt{ }$ & & \\
\hline \multicolumn{2}{|l}{ E Skor yang diperoleh } & & $\mathbf{1 2}$ & $\mathbf{1 2}$ & \\
\hline
\end{tabular}


Keterangan:

Skor 4 = Sangat Baik

Skor 2 = Kurang Baik

Skor 3 = Baik

Skor 1 = Sangat Tidak Baik

Berdasarkan tabel di atas aspek-aspek yang mendapat kriteria kurang baik adalah Minat belajar siswa, keseriusan siawa, Keaktifan siswa, kerjasama antar siswa, ketertiban siswa, dan keriuhan dan gerak - gerik siswa.

Adapun hasil siklus kedua sebagai berikut:

1. Proses Pembelajaran Kelas

Tabel 4.8 Pengamatan proses pembelajaran siklus kedua

\begin{tabular}{|c|l|c|c|c|c|}
\hline No & \multicolumn{1}{|c|}{ Obyek yang diamati } & $\mathbf{4}$ & $\mathbf{3}$ & $\mathbf{2}$ & $\mathbf{1}$ \\
\hline 1 & Minat belajar siswa dalam pembelajaran & $\sqrt{ }$ & & & \\
\hline 2 & Kesungguh-sungguhan siswa & & $\sqrt{ }$ & & \\
\hline 3 & Keseriusan siswa & $\sqrt{ }$ & & & \\
\hline 4 & Keaktifan siswa selama pembelajaran & $\sqrt{ }$ & & & \\
\hline 5 & Kerjasama antar siswa dalam kelompok & & $\sqrt{ }$ & & \\
\hline 6 & Kehangatan suasana pembelajaran & & $\sqrt{ }$ & & \\
\hline 7 & Ketertiban siswa & & $\sqrt{ }$ & & \\
\hline 8 & Keriuhan dan gerak-gerik siswa & & $\sqrt{ }$ & & \\
\hline 9 & Kelancaran langkah-langkah pembelajaran & $\sqrt{ }$ & & & \\
\hline 10 & Ketepatan selesainya proses pembelajaran & & $\sqrt{ }$ & & \\
\hline \multicolumn{2}{|c}{ Skor yang diperoleh } & $\mathbf{1 6}$ & $\mathbf{1 8}$ & & \\
\hline
\end{tabular}

Keterangan:

Skor 4 = Sangat Baik

Skor 3 = Baik

Skor 2 = Kurang Baik

Skor 1 = Sangat Tidak Baik

Berdasarkan tabel di atas sudah tampak bahwa keseluruhan pembelajaran

pada siklus kedua berjalan dengan baik dan lancar serta tidak ada aspek yang kurang baik.

Tabel 4.15 Perbandingan Peningkatan Hasil Belajar Siklus pertama dan

Siklus Kedua

\begin{tabular}{|c|c|c|c|}
\hline \multirow{2}{*}{ No } & \multirow{2}{*}{ Jenis Penilaian } & \multicolumn{2}{|c|}{ Rata-Rata } \\
\cline { 3 - 4 } & & Siklus 1 & Siklus 2 \\
\hline 1 & Psikomotor & 22,38 & 30,45 \\
\hline 2 & Afektif & 15 & 21 \\
\hline 3 & Kognitif & 17.5 & 17.5 \\
\hline
\end{tabular}




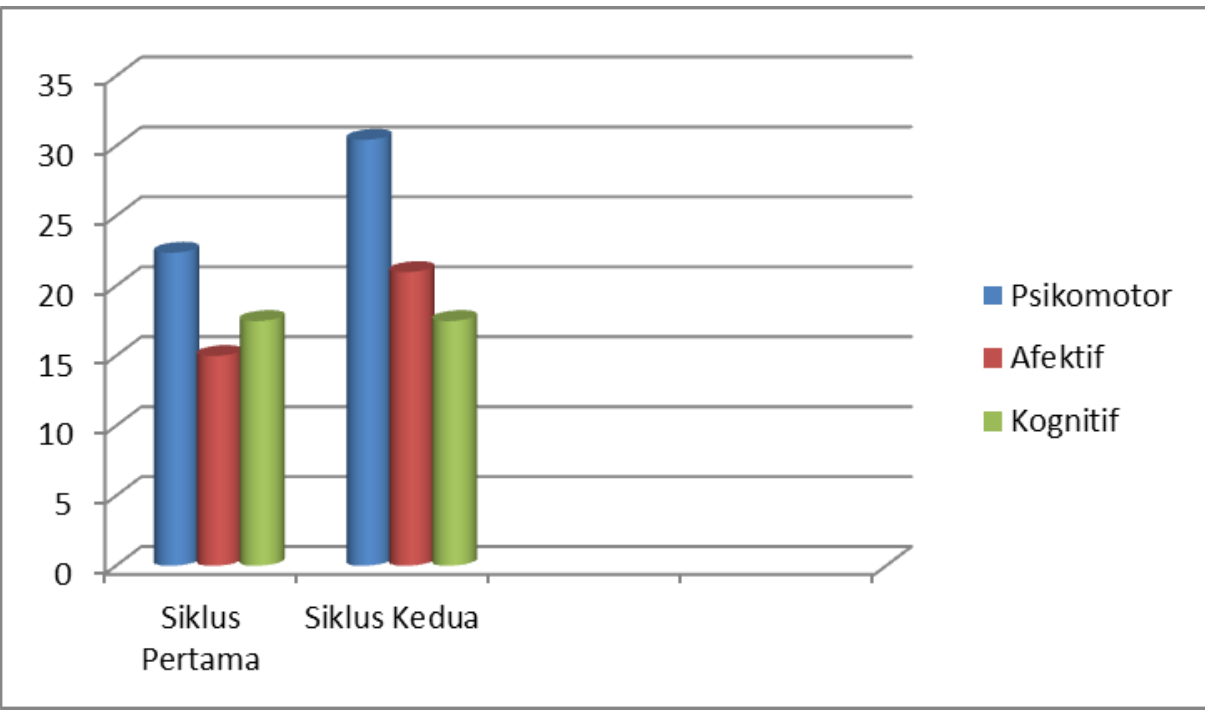

Gambar 4.5 Diagram Perbandingan Aspek Psikomotor, Afektif, dan

Kognitif

\section{SIMPULAN}

Berdasarkan penelitian yang telah dilakukan oleh peneliti pada peserta didik kelas X MM SMKN 1 Jatirejo tahun 2017/2018, maka telah dapat di peroleh kesimpulan yaitu bahwa adanya peningkatan hasil belajaran servis bawah bolavoli dengan metode pembelajaran problem solving pada pra siklus atau sebelum dilakukan tindakan menunjukan tingkat belajar sebesar $56 \%$ dan pada siklus 1 menunjukan tingkat belajar servis bawah bolavoli sebesar $60 \%$ dan pada siklus ke 2 menunjukan peningkatan hasil belajar servis bawah sebesar $80 \%$. Berdasarkan dari pra siklus dan setelah dilakukan tindakan pada siklus 1 dan siklus 2, diketahui bahwa adanya peningkatan hasil belajar servis bawah bolavoli dengan menggunakan metode problem solving, dari hasil peningkatan belajar servis bawah bolavoli yang telah dilakukan, maka diperoleh berdasarkan pra siklus dan setelah tindakan siklus 1 dan siklus 2 yaitu telah dapat meningkatkan hasil belajar servis bawah bolavoli. Dengan demikian maka penelitian tindakan kelas yang dilakukan dapat dinyatakan berhasil, karena telah 
mengalami peningkatan diatas dari nilai indikator keberhasilan yang telah ditetapkan yaitu sebesar $70 \%$.

Berdasarkan simpulan yang dikemukakan peneliti di atas, saran yang dapat diambil oleh peneliti dengan hasil penelitian yang telah dilakukan diantaranya:

1. Bagi guru Pedidikan Jasmani dan Kesehatan, diharapkan dapat digunakan sebagai bahan pertimbangan untuk memilih metode pembelajaran sehingga siswa dapat termotivasi dan merasa senang mengikuti proses pembelajaran.

2. Bagi siswa, diharapkan siswa mengerti bahwa dengan metode pembelajaran problem solving juga dapat meningkatkan hasil belajar servis bawah bolavoli.

3. Bagi peneliti lain, dapat dijadikan acuan penelitian tentang pendidikan jasmani dan kesehatan serta dapat dijadikan sebagai wawasan baru, khususnya dalam pengembangan metode pembelajaran.

\section{DAFTAR PUSTAKA}

Ahmadi, dkk. 2011. Strategi Pembelajaran Sekolah Terpadu. Jakarta: PT. Prestasi Pustakarya

Aqib, Zainal. 2006. Penelitian Tindakan Kelas. Irama Widya

Arikunto, Suharsimi. 2010. Penelitian Tindakan Kelas. Jakarta: Bumi Aksara

Atmasubrata, Ginanjar. 2012. Serba Tahu Dunia Olahraga. Surabaya: DAFA Publishing

Budiningsih, Asri. 2005. Belajar dan Pembelajaran. Jakarta: Rineka Cipta

Dimyanti, dan Mudjiono. 2009. Belajar dan Pembelajaran. Jakarta: Rineka Cipta

Ekawarna. 2011. Penelitian Tondakan Kelas. Jakarta: Gp Press

Fadillah Muhammad.2012. Desain Pembelajaran Paud. Yogyakarta: Acruzz Media 
Haryanti. 2010. Penerapan model Pembelajaran Problem Solving Sebagai Upaya untuk Meningkatkan Keaktifan dan Prestasi Belajar Siswa Kelas VII Mata Pelajaran IPS Terpadu SMP Negeri 2 Jatiyoso Tahun Ajaran 2009/2010.

Skripsi. Surakarta: Universitas Sebelas Maret. Skripsi tidak diterbitkan

Hidayatulloh, Arif. 2013. Pembelajaran Passing dan Control Melalui Media Permainan Kucing-Kucingan Bagi Siswa Kelas V SDN Pencabean 02 Kecamatan Pangkah Kabupaten Tegal. Skripsi. Semarang: Universitas Negeri Semarang. Skripsi tidak diterbitkan

Huda, Miftahul. 2013. Model-Model Pengajaran dan Pembelajaran. Malang: Pustaka Pelajar

Manik, Agung Cristo. 2015. Penerapan Saintifik Melalui Gaya Mengajar Pemecahan Masalah Pada Passing Bawah BolaVoli. Jurnal.Serdang: Padagogik Keolahragaan

PBVSI. 2005. Peraturan Permainan Bola Voli. Jakarta: PP. PBVSI

Permana, Yoga S. 2008. Bermain dan Olahraga Bola Voli. Surabaya: Insan Cendekia

Sardiman, A. 2009. Interaksi dan Motivasi Belajar-Mengajar. Jakarta: Rajawali Pers

Septyadi, Wisnu. 2013. Upaya Peningkatan Hasil Belajar Servis Bawah BolaVoli Mini Melalui Bola DEngan Ukurannya Siswa Kelas IV SD Negeri Pecarikan Kecamatan Prembun kabupaten Kebumen Tahun Pelajaran 2012/2013. Jurnal Fakultas Keguruan Dan IImu Pendidikan Universitas Sebelas Maret Surakarta.

Syah Muhibbin 1995 Psikologi Pendidikan Dengan Pendekatan Baru. Bandung: Remaja Rosdakarya

Sudjana, Nana. 2011. Penilaian hasil proses belajar mengajar. Bandung: PT. Remaja Rosdakarya Offset.

Sukintaka. 2008 Teori Pendidikan Jasmani. Bandung: Yayasan Nuansa Cendekia

Suwandi,Fendy Aprianto. 2016. Peningkatan Hasil Belajar Passing Bawah BolaVoli Dengan Model Pembelajaran Problem Solving Pada Siswa Kelas V SDN Sambirejo 3 Wonosalam Kabupaten Jombang Tahun Pelajaran 2016/2017.Skripsi. Sekolah Tinggi Keguruan Ilmu Pendidikan Perguruan Tinggi Republik Indonesia. Jombang. Skripsi tidak diterbitkan

Winarno, M.E. 2006. Tes Keterampilan Olahraga. Malang: Laboratorium Jurusan Ilmu Keolahragaan 
Yunus, M. 1992. Olahraga Pilihan Bola Voli. Jakarta: Departemen Pendidikan dan Kebudayaan Direktorat Jenderal Pendidikan Tinggi Proyek Pembinaan Tenaga Kependidikan 